\title{
The Sodium/Glucose Co-Transporter Inhibitors are a Growing Repository for Treating Diabetes
}

\section{Introduction}

The sodium/glucose co-transporter (SGLT) is a new class of antidiabetic drugs. These drugs act on a unique target in kidneys causing loss of glucose in urine. The glucosuric effect is produced by inhibition of the renal $\mathrm{Na}$ /glucose co-transporter that will lead to a unique hypoglycemic, hypotensive and favourable weight loss. For this novel mechanism of action, SGLT inhibitors can be used for both type 1 and type 2 diabetic cases. Drug discovery and introduction of new SGLT inhibitors is still growing and more drugs are expected to be introduced. This is enforced by the high selectivity and efficacy of the novel inhibitors.

\section{Diabetes}

Diabetes mellitus (DM) comprises chronic sugar toxicity due to loss of control on the blood sugar level. The human pancreas secretes two important hormones that control the blood glucose level. The first is insulin which lowers the blood glucose level. In contrast, glucagon increases the level of blood sugar. Disturbance in the pancreatic function or peripheral response to pancreatic hormones will lead to diabetic conditions (Figure 1). There are two main types of DM. Type 1 DM (insulin dependent $\mathrm{DM}$ ) in which there is progressive loss of pancreatic beta cells leading to loss of endogenous production of insulin. Therefore, patients of this type will depend on external source of insulin during the rest of their lives. In type $2 \mathrm{DM}$, there is normal or subnormal levels of endogenous insulin. However, the peripheral tissues are devoid of sufficient response to insulin action (insulin resistance). The complications of diabetes include microvascular and neurological complications that interfere with major body functions and causing disorders as retinopathy, renopathy, cardiopathy, neuropathy and other complications [1-3].

\section{Treatment of DM}

\section{Type 1 DM}

Insulin is the choice for type 1 DM. The required dose of insulin, frequency and type of insulin are determined on individual bases.

\section{Type II diabetes}

Oral hypoglycemics, diet restrictions, exercise and/or insulin are required for type 2 DM (Table 1 ).

\section{Kandeel M and Alhamama M}

\begin{abstract}
Department of Physiology, Biochemistry and Pharmacology, Faculty of Veterinary Medicine and Animal Resources, King Faisal University, Alahsa, Saudi Arabia.
\end{abstract}

Corresponding author: Kandeel, $\mathrm{M}$.

” mkandeel@kfu.edu.sa

\section{Role of Kidney in Glucose Homeostasis}

Kidney is a major organ in glucose homeostasis. The normal kidney reabsorbs the filtered glucose into the circulation. It is estimated that about 180-220 gram of glucose are reabsorbed into the circulation again after being filtered from the blood [4]. This function is managed by an efficient glucose transport system in the renal tubules. This system includes two important glucose transporters called sodium/glucose co-transporters (SGLTs). There are two main types of SGLTs involved in glucose transport, SGLT1 and SGLT2. The differences between these two transporters are summarized in Table 2.

\section{SGLT inhibitors}

SGLT inhibitors act by inhibiting SGLT leading to loss of glucose in

Table 1. Hypoglycemic agents for type 2 DM.

\begin{tabular}{|c|c|c|}
\hline Hypoglycemics & Action & Examples \\
\hline \multicolumn{3}{|l|}{ 1. Insulin sensitizers } \\
\hline Biguanides & $\begin{array}{l}\text { Decrease liver glucose output } \\
\text { and increase sensitivity to } \\
\text { insulin }\end{array}$ & Metformin \\
\hline Thiazolidinediones & $\begin{array}{l}\text { Enhance the sensitivity of } \\
\text { peripheral tissues to insulin } \\
\text { action }\end{array}$ & Pioglitazone \\
\hline \multicolumn{3}{|c|}{ 2. Insulin secretagogues } \\
\hline Sulphonylurea & Stimulate secretion of insulin & Clibenglamide \\
\hline $\begin{array}{l}\text { DPP-4 inhibitors } \\
\text { and incretin } \\
\text { analogues }\end{array}$ & Stimulate insulin secretion & Vildagliptin \\
\hline \multicolumn{3}{|c|}{ 3. Enhance low glucose absorption or increased excretion } \\
\hline $\begin{array}{l}\text { Alfa glucosidase } \\
\text { inhibitors }\end{array}$ & $\begin{array}{l}\text { Prevent digestion of } \\
\text { carbohydrates in gut }\end{array}$ & Acarbose \\
\hline SGLT inhibitors & $\begin{array}{l}\text { New class of antidiabetic drugs } \\
\text { act by prevention of renal } \\
\text { reabsorption of glucose }\end{array}$ & $\begin{array}{c}\text { Dapagliflozin, } \\
\text { canagliflozin }\end{array}$ \\
\hline
\end{tabular}


Table 2. The major differences between SGLT1 and SGLT2.

\begin{tabular}{|c|c|c|}
\hline & $\begin{array}{l}\text { Sodium glucose co-transporter1 } \\
\text { (SGLT1) }\end{array}$ & $\begin{array}{l}\text { Sodium glucose co-transporter2 } \\
\text { (SGLT2) }\end{array}$ \\
\hline $\begin{array}{l}\text { Location in } \\
\text { kidney }\end{array}$ & In S3 segment of proximal tubules & In S1 of proximal tubules \\
\hline $\begin{array}{l}\text { Capacity } \\
\text { of glucose } \\
\text { transport }\end{array}$ & Low capacity & High capacity \\
\hline $\begin{array}{l}\text { Affinity of } \\
\text { glucose binding }\end{array}$ & High affinity & Low affinity \\
\hline $\begin{array}{l}\text { Contribution } \\
\text { to glucose } \\
\text { reabsorption }\end{array}$ & 10\% & $\sim 90 \%$ \\
\hline $\begin{array}{c}\text { Organs of } \\
\text { highest } \\
\text { expression level }\end{array}$ & Intestine & Kidney \\
\hline $\begin{array}{l}\text { Result of } \\
\text { inhibition }\end{array}$ & Diarrhea & Glucosuria \\
\hline
\end{tabular}

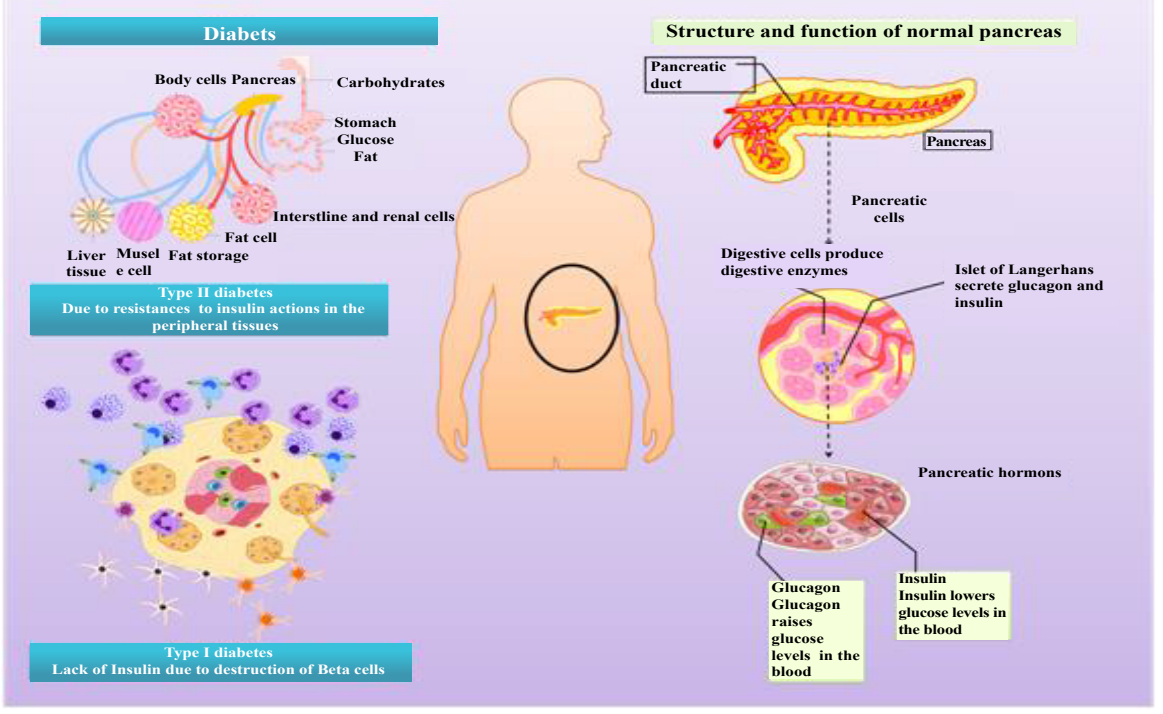

Figure 1 The physiological and pathological aspects of pancreatic endocrine function.

urine. The action of SGLTs is depending on the amount of filtered glucose. Therefore higher amount of glucose loss is expected during glucosuria. The concept of SGLT inhibition and its related antidiabetic effect was introduced in 2001 [5]. The first compound known to inhibit glucose reabsorption was phlorizin (isolated from the bark of apple tree), which was used as antipyretic and induced glucosuria. Several phlorizin derivatives were tested for their antidiabetic efficiency [5]. This concept was first introcduced and followed by extensive drug discovery studies to find new SGLT inhibitors (Fujimori et al., 2008; Gao et al., 2010; Katsuno et al., 2007; Meng et al., 2008; Nomura et al., 2010; Ohsumi et al., 2003; Tsujihara et al., 1996; Tsujihara et al., 1999; Zhou et al., 2010). Recently, three SGLT inhibitors are approved for clinical use in treatment of DM, dapagliflozin, canagliflozin and empagliflozin (Figure 2) [6,7]. Other SGLT inhibitors under preclinical studies include ipragliflozin, sergliflozin remoglilozin, , and tofogliflozin [8].

\section{Development of New Inhibitors}

Drug discovery is the only reliable way to combat the infectious and noninfectious disease by using various in silico and in vivo techniques. In this context, mechanisms that are unique to the foreign organism or affected in the host at very low concentrations can be targeted to combat diseases [9-12]. SGLT inhibitors showed extensive drug discovery studies that lead to discovery of hundreds of new SGLT inhibitors and many other are still under development. The wide variety of chemical modifications and its favourable inhibitory properties accounts for the growing repository of SGLT inhibitors. in the development of new SGLT inhibitors, two critical measurements are to be considered. The first is the potency of SGLT2 inhibition and the second is the selectivity of SGLT2 over SGLT1. The desired drugs could have higher selectivity for SGLT2 to avoid the side effects produced after inhibition of SGLT1. Table 3 summarizes the inhibitory properties and selectivity of some SGLT inhibitors (the best compound in each group). 


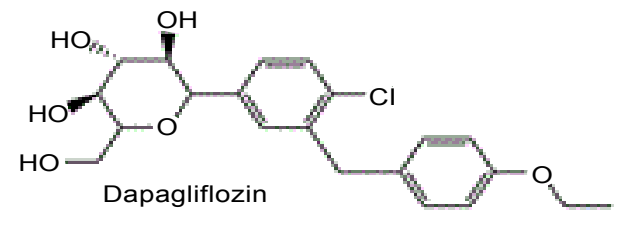<smiles>Cc1ccc(C2OC(CO)[C@@H](O)[C@H](O)[C@H]2O)cc1Cc1ccc(-c2ccc(F)cc2)s1</smiles>

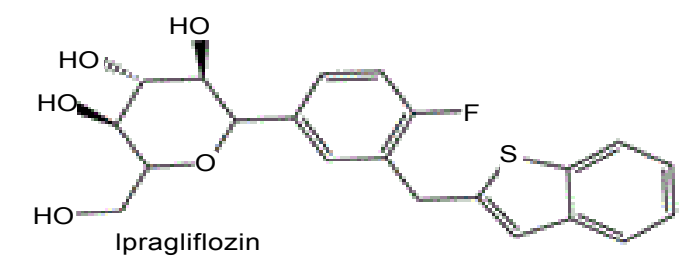<smiles>OCC1OC(c2ccc(Cl)c(Cc3ccc(O[C@H]4CCOC4)cc3)c2)C(O)[C@@H](O)[C@H]1O</smiles>
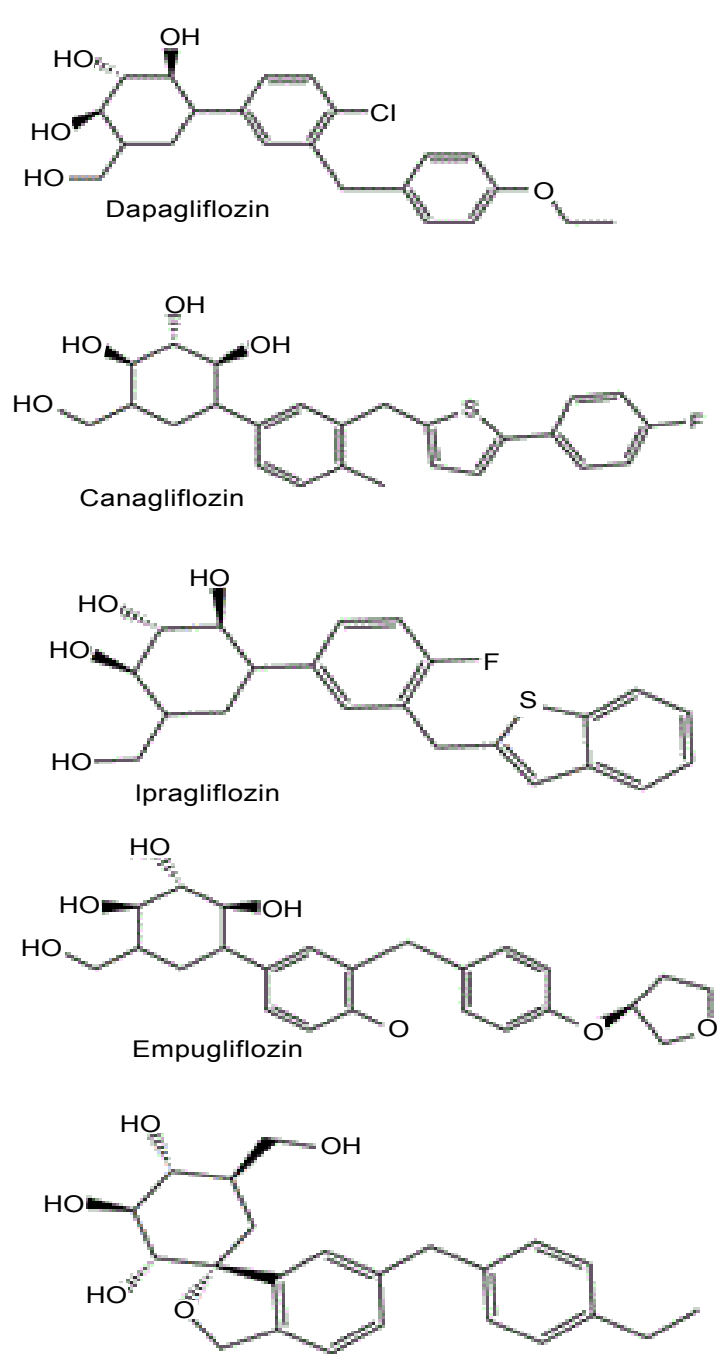

Tofogliflozin

Figure 2 SGLT inhibitors.

Table 3. Examples of SGLT inhibitors drug development trials.

\begin{tabular}{|c|c|c|c|}
\hline Nature of chemical modifications & $\begin{array}{l}\text { SGLT IC }_{50} \\
\text { (nM) }\end{array}$ & Selectivity (fold) & Reference \\
\hline $\begin{array}{l}\text { L-rhamnose derived acyclic } \\
\text { C-nucleosides }\end{array}$ & 314.6 & 2.3 & [13] \\
\hline $\begin{array}{l}\text { C-glycoside with } \\
\text { benzyltriazolopyridinone and } \\
\text { phenylhydantoin }\end{array}$ & 33 and 10.9 & 1750 & [14] \\
\hline C-glycoside with azulene rings & 22 & 590 & [8] \\
\hline $\begin{array}{l}\text { gem-difluoromethylenated } \\
\text { Dapagliflozin analogs }\end{array}$ & 0.35 & & [15] \\
\hline C-indolylxylosides & 2.4 & 247 & [16-20] \\
\hline ortho-Substituted C-aryl glucosides & 0.3 & 3300 & [15] \\
\hline $\begin{array}{l}\text { C-glycoside with } \\
\text { thiadiazolylmethlphenyl derivatives }\end{array}$ & 3 & - & [21] \\
\hline $\begin{array}{l}\text { C-aryl glucoside with } \\
\text { Pyridazinylmethylphenyl congeners }\end{array}$ & 11.4 & & {$[22]$} \\
\hline C-5-spirocyclic C-glycoside & 3.4 & 1500 & [23] \\
\hline C-5 spirocyclization & 3.4 & 1500 & {$[14]$} \\
\hline O-spiroketal C-arylglucosides & 3.8 & 184 & [24] \\
\hline
\end{tabular}




\section{References}

1 Arakawa K, Ishihara T, Oku A, Nawano M, Ueta K, et al. (2001) Improved diabetic syndrome in $\mathrm{C} 57 \mathrm{BL} / \mathrm{KsJ}-\mathrm{db} / \mathrm{db}$ mice by oral administration of the $\mathrm{Na+}$-glucose cotransporter inhibitor T-1095. British journal of pharmacology 132: 578-586.

2 Balakumar P, Sundram K, Dhanaraj SA (2014) Dapagliflozin: Glucuretic action and beyond. Pharmacological Research 82: 34-39.

3 Chen Z-H, Wang R-W, Qing F-L (2012) Synthesis and biological evaluation of SGLT2 inhibitors: gem-difluoromethylenated Dapagliflozin analogs. Tetrahedron Letters 53: 2171-2176.

4 Demidova-Rice TN, Hamblin MR, Herman IM (2012) Acute and impaired wound healing: pathophysiology and current methods for drug delivery, part 1: normal and chronic wounds: biology, causes, and approaches to care. Advances in skin \& wound care 25: 304 .

5 Ferrannini E, Seman L, Seewaldt-Becker E, Hantel S, Pinnetti S, et al. (2013) A Phase Ilb, randomized, placebo-controlled study of the SGLT2 inhibitor empagliflozin in patients with type 2 diabetes. Diabetes, Obesity and Metabolism 15: 721-728.

6 Fujimori Y, Katsuno K, Nakashima I, Ishikawa-Takemura Y, Fujikura $\mathrm{H}$, et al. (2008) Remogliflozin etabonate, in a novel category of selective low-affinity sodium glucose cotransporter (SGLT2) inhibitors, exhibits antidiabetic efficacy in rodent models. Journal of Pharmacology and Experimental Therapeutics 327: 268-276.

7 Gao Y, Zhao G, Liu W, Shao H, Wang Y, et al. (2010) Design synthesis and in vivo hypoglycemic activity of tetrazole-bearing $\mathrm{N}$-glycosides as SGLT2 inhibitors. Indian journal of chemistry. Section B, Organic including medicinal 49: 1499.

8 Grempler R, Thomas L, Eckhardt M, Himmelsbach F, Sauer A, et al. (2012) Empagliflozin, a novel selective sodium glucose cotransporter-2 (SGLT-2) inhibitor: characterisation and comparison with other SGLT-2 inhibitors. Diabetes, Obesity and Metabolism 14: 83-90.

9 Guo C, Hu M, DeOrazio RJ, Usyatinsky A, Fitzpatrick K, et al. (2014) The design and synthesis of novel SGLT2 inhibitors: C-glycosides with benzyltriazolopyridinone and phenylhydantoin as the aglycone moieties. Bioorganic \& medicinal chemistry 22: 3414-3422.

10 Kandeel M, Elaiziz M, Kandeel A, Altaher A, Kitade Y (2014a): Association of host tropism of Middle East syndrome coronavirus with the amino acid structure of host cell receptor dipeptidyl peptidase 4. Acta virologica 58: 359.

11 Ikegai K, Imamura M, Suzuki T, Nakanishi K, Murakami T, et al. (2013) Synthesis and biological evaluation of C-glucosides with azulene rings as selective SGLT2 inhibitors for the treatment of type 2 diabetes mellitus: Discovery of YM543. Bioorganic \& medicinal chemistry 21: 3934-3948.

12 Kandeel M (2014) Bioinformatics analysis of the recent MERS
CoV with special reference to the virus-encoded Spike protein. Molecular Enzymology and Drug Targets 1.

13 Meng W, Ellsworth BA, Nirschl AA, McCann PJ, Patel M, et al. (2008) Discovery of dapagliflozin: a potent, selective renal sodium-dependent glucose cotransporter 2 (SGLT2) inhibitor for the treatment of type 2 diabetes. Journal of medicinal chemistry 51: 1145-1149.

14 Kandeel M, Noguchi Y, Oh-Hashi K, Kim H-S, Kitade Y (2014b): Molecular dynamics and energetic perceptions of substrate recognition by thymidylate kinase. Journal of Thermal Analysis and Calorimetry 115: 2089-2097.

15 Robinson RP, Mascitti V, Boustany-Kari CM, Carr CL, Foley, et al. (2010) C-Aryl glycoside inhibitors of SGLT2: exploration of sugar modifications including C-5 spirocyclization. Bioorganic \& medicinal chemistry letters 20: 1569-1572.

16 Tsujihara K, Hongu M, Saito K, Inamasu M, Arakawa K, (1996) Na (+)-glucose cotransporter inhibitors as antidiabetics. I. Synthesis and pharmacological properties of 4'-dehydroxyphlorizin derivatives based on a new concept. Chemical \& pharmaceutical bulletin 44: 1174-1180.

17 Lee J, Lee S-H, Seo HJ, Son E-J, Lee SH, et al. (2010) Novel C-aryl glucoside SGLT2 inhibitors as potential antidiabetic agents: 1,3,4-Thiadiazolylmethylphenyl glucoside congeners. Bioorganic \& medicinal chemistry 18: 2178-2194.

18 Lv B, Xu B, Feng Y, Peng K, Xu G, et al. (2009) Exploration of $\mathrm{O}$-spiroketal $\mathrm{C}$-arylglucosides as novel and selective renal sodiumdependent glucose co-transporter 2 (SGLT2) inhibitors. Bioorganic \& medicinal chemistry letters 19: 6877-6881.

19 Mascitti V, Robinson RP, Préville C, Thuma BA, Carr CL, et al. (2010) Syntheses of C-5-spirocyclic C-glycoside SGLT2 inhibitors. Tetrahedron Letters 51: 1880-1883.

20 Kandeel M, Ando T, Kitamura Y, Abdel-Aziz M, Kitade Y (2009) Mutational, inhibitory and microcalorimetric analyses of Plasmodium falciparum TMP kinase. Implications for drug discovery. Parasitology 136: 11-25.

21 Nomura S, Sakamaki S, Hongu M, Kawanishi E, Koga Y, et al. (2010) Discovery of canagliflozin, a novel C-glucoside with thiophene ring, as sodium-dependent glucose cotransporter 2 inhibitor for the treatment of type 2 diabetes mellitus (1). Journal of medicinal chemistry 53: 6355-6360.

22 Ohsumi K, Matsueda H, Hatanaka T, Hirama R, Umemura (2003) Pyrazole-O-glucosides as novel Na+-glucose cotransporter (SGLT) inhibitors. Bioorganic \& medicinal chemistry letters 13: 2269-2272.

23 Pasnoor M, Dimachkie MM, Kluding P, Barohn RJ (2013) Diabetic neuropathy part 1: overview and symmetric phenotypes. Neurologic clinics 31: 425-445.

24 Putapatri SR, Kanwal A, Banerjee SK, Kantevari S (2014) Synthesis of novel I-rhamnose derived acyclic C-nucleosides with substituted 1,2,3-triazole core as potent sodium-glucose co-transporter (SGLT) inhibitors. Bioorganic \& medicinal chemistry letters 24: 1528-1531. 